\title{
The Allegation of Working From Home in Influencing Consumer Purchasing Decisions Through E-Commerce
}

\author{
Dorothy Rouly Haratua Pandjaitan \\ \{dorothy.rouly81@gmail.com\}
}

Faculty of Economics and Business, University of Lampung, Lampung-Indonesia

\begin{abstract}
The purpose of this research was conducted to determine the effect of Work From Home on purchasing decisions via e-commerce during lockdown to reduce the chain of the corona virus. The number of positive patients infected with the Corona Virus in Indonesia, amounting to 1,790 people as of April $1^{\text {st }}$, 2020 , underlies several freight forwarding companies to take anticipatory steps to minimize the spread of the virus while continuing to carry out operational activities. Although online trading activities are considered to be the best solution that can be done to reduce consumer concerns and also prevent the risk of human-tohuman transmission, of course there are special regulations and preventive measures imposed by freight companies in pandemic conditions like this.
\end{abstract}

Keywords: Purchasing Decision, Corona Virus, E-Commerce, Work From Home.

\section{Introduction}

The Corona virus (Covid-19) has a significant impact on the economies of the countries affected by the virus. In a situation related to the spread of the Corona Virus as it is today, several countries including Indonesia have begun to implement anticipatory steps to minimize the spread of the virus. Some anticipatory steps aimed at suppressing the spread of Corona Virus include policies to keep social distancing and work from home (wfh) for employees in some companies. Preventive measures that have been appealed by the central government and a number of local governments to anticipate the increasingly widespread outbreak of Corona Virus in order to break the chain of transmission of this virus have several implications in some sectors, especially in the logistics sector. The spread of the Corona Virus and the introduction of lockdowns or restrictions on movement of people, goods, and money, have accelerated the use of new digital technologies and tools that have and have not been used by all people around the world. When consumers are locked out, millions of people are forced to work and move from home. Thus, the solution of that is digital and technology.

The enforcement of human movement restrictions automatically makes people more active in finding solutions that enable technology to assist in everyday tasks, such as shopping or working remotely from home. For example, shopping for some consumers may be taken as a totally new behavior. Like shopping for groceries or medicines online for the first time, but for others, this may be an increase in online use or the addition of new technologies, tools and software to support remote activities, such as using Google Conference, Hangouts, Skype Zoom and more. Initially, consumers used technology to find information and news about the Corona Virus circulation, but this became a bridge or catalyst for the acceleration of the adoption of digital use and technology more broadly, including how to shop online or e-commerce.

Consumer behavior is a unique phenomenon to be studied and observed. Consumer behavior can be said as the estuary of various economic theories, because all economic activities will be related to an end to the attitudes or behavior of consumers. Various theories about consumer behavior, one of the most influential consumer behavior in economic activity is the purchase decision, because the purpose of an economic activity from production to marketing aims to make consumers make purchases of the product. But before a consumer makes a purchasing decision he will be influenced by factors that affect him on the product, and these factors can come from the customer's own internal and external consumers.

\section{Literature Review Consumer Behavior}

Consumer behavior is the study of how individuals, groups, and organizations choose, buy, use and how goods, services, ideas, or experiences to include their needs and desires [1]. Consumers are an important part of the sustainability of a company, so it requires companies to be better understand and know the behavior of their consumers, and how companies provide quality products to consumers. 


\section{E-Commerce}

In the present time, the definition of e-commerce which has become an international standard and which has been mutually agreed upon, still does not exist. But in general, we can interpret that e-commerce is a dynamic set of technologies, applications, and business processes that link enterprises, customers, and communities through electronic transactions and electronic exchange of goods, services and information [2].

According to Mariza Arfina and Robert Marpuang, e-commerce or commonly known as e-com, can be interpreted as a way to shop or trade online or direct selling that utilizes internet facilities where there are websites that provide "get and deliver" services.

\section{Purchase Decision}

Complicated decision making often involves several decisions. A decision involves a choice between two or more alternative actions (or behaviors). Decisions always require a choice between several different behaviors. Consumer decision making is an integration process that combines knowledge to evaluate two or more alternative behaviors and choose one of them [3]. Consumer purchasing decisions, could not be separated from how consumers go through several stages, namely knowing the problems faced until the occurrence of consumer purchase transactions [4].

\section{Purchase Decision Process Stage}

According to [5] stages of the consumer purchasing decision process are mentioned as follows:

1. Introduction of needs

The buying process begins with a problem or need that has not been satisfied and can be felt by consumers. Consumers prepare the difference between what is desired and the current situation in order to arouse and activate the decision process. These needs may have been known and felt by consumers far from before.

2. Search for information

After consumers are aware of the need for an item or service, then consumers look for information, both stored in memory and information obtained from the outside environment.

3. Alternative evaluation

After the information is obtained, consumers evaluate various alternative choices in meeting those needs.

4. Purchase decisions

If there are no other disturbing factors after the consumer makes the choice, the actual purchase is the final result of the search and evaluation.

5. Behavior after purchase

In general, if an individual feels a very strong interest or satisfaction in meeting a need, he will usually keep that in mind. Post-purchase behavior includes post-purchase satisfaction, post-purchase actions, and product usage.

\section{Work From Home}

Work from home is a term of working remotely, more precisely working from home (wfh). So workers do not need to come to the office, face to face with other workers. Work from home is no stranger to freelancer workers, but they more often call it remote work or remote working. Work from home and remote working actually make no difference to the term alone, the only difference being the rules of the company they work for. Some apply normal working hours 8 am to $4 \mathrm{pm}$ or free work hours as long as work is done and communication is always fast response.

According to Working from home means paid work done mainly from home (at least 20 hours per week) [6]. Working from home will provide flexible time for workers to provide life balance for employees. On the other hand, it also provides benefits for the company. WFH is an abbreviation of work from home, which means working directly from the place where we live. Generally, work from home is defined as the way employees work outside the office. Whether from home, from a cafe or restaurant in accordance with the wishes of employees. WFH work system does have high flexibility. This is to support the balance of employees between work and life. But in fact now wfh is being the solution because of the corona virus outbreak. This is to reduce the risk of corona virus transmission and employee safety [7]. 


\section{Hypothesis}

Hypothesis is a statement that is temporary guess about the relationship between two or more variables. Based on the above theory the following hypotheses can be drawn "The Allegation of Working From Home in Influencing Consumer Purchasing Decisions through E-commerce".

\section{Research Method}

According to [8] in the Research Method for Business, the descriptive method is a method of examining the status of a group of people, an object, a set of conditions, a system of thought or a class of events at the present time. The purpose of this descriptive study is to make a systematic, factual and accurate description, or painting of the facts, traits and relationships between the phenomena investigated. According to [9] stated that the descriptive method is a method used to describe or analyse a research result but is not used to make broader conclusions.

The subjects in this study are very limited considering time limit. This study uses data available on the internet and also in books. In this study, the data obtained from surveying the internet and books.

\section{Analysis Data Method}

In this study using descriptive statistics that is by describing the data of each variable.

\section{Variable Operational Definition}

In this study the variables used are:

Work From Home as X variable, namely WFH is an abbreviation of work from home, which means working from home. Generally, work from home is defined as the way employees work outside the office. Whether from home, from a cafe or restaurant in accordance with the wishes of employees. WFH work system does have high flexibility. This is to support the balance of employees between work and life.

The purchase decision as a variable $\mathrm{Y}$ is the step by step used by consumers when buying goods and services. With indicators used, they are 1). Recognition of needs (Problem / Need Recognition). 2). Information Search. 3). Information Evaluation. 4). Decision to buy.

\section{Results And Discussion}

The high growth of online trade has made Indonesia one of the countries in Southeast Asia that has a large potential market in the economic sector. This relates to the courier industry which delivers goods to consumers and the warehousing sector as a place to store goods.

The rapid growth of e-commerce orders also occurred in March 2020, precisely after the Corona Virus outbreak (Covid-19) spread in Indonesia. Corona virus has a significant impact on the economy in countries affected by the virus, including Indonesia.

The increase in digital spending occurs because people prefer to buy their needs online, this is in line with the adoption of government policies namely work from home or work from home (WFH) as well as an extension of the study period at home. The spread of the Corona Virus and the introduction of lockdowns or restrictions on movement of people, goods, and money, has accelerated the use of new digital technologies and tools that have and have not been used by all people of the world. When consumers are locked out, millions of people are forced to work and move from home. So the solution of that is digital and technology.

The enforcement of human movement restrictions automatically makes people more active in finding solutions that enable technology to assist in everyday tasks, such as shopping or working remotely from home. For example shopping, for some consumers may be a totally new behavior. Like shopping for groceries or medicines online for the first time, but for others, this may be an increase in online use or the addition of new technologies, tools and software to support remote activities, such as using Google Conference, Hangouts, Skype Zoom and more.

Initially, consumers used technology to find information and news about the Corona Virus circulation, but this became a bridge or catalyst for the acceleration of the adoption of digital use and technology more broadly, including how to shop online or e-commerce.

Sudden growth in demand based on product categories is divided into four groups including:

- The category groups are related to health and self-protection such as insurance, immune immunity supplement products, to sanitary self-protection products such as hand sanitizers, medicines, and vitamins. 
- The category of household and kitchen needs categories such as food stock, including basic food needs such as sugar, rice, instant noodles, to snacks for needs when the work from home policy is implemented. This fast moving consumer goods (FMCG) product group experienced an increase in e-commerce channels.

- Entertainment and fitness product category groups. The implementation of social distancing and WFH policies caused many families to make the decision to spend time together at home. Product groups for family entertainment such as game consoles and independent sports equipment such as fitness equipment and gyms more than doubled this March

- Group categories related to worship. There are restrictions on people gathering, including to perform the worship process in congregation resulting in increased demand for worship equipment.

If we often visit e-commerce recently, they are competing in attracting customers to shop only through the house to reduce the risk of the spread of Covid-19. Many promos that they provide such as free promo postage to discounted prices that can attract consumers. The growth of e-commerce in the current conditions opens great opportunities for freight forwarding services between regions, both domestic and abroad to be able to contribute to the shipping process. Courier services also play an important role in supporting the smooth business of a company that requires delivery services quickly and safely.

Since the spread of Corona Virus in Indonesia, a number of freight forwarding companies recorded an increase in freight shipments reaching $80 \%$. In the current condition, around $60 \%$ to $70 \%$ of the company's goods shipping transactions come from e-commerce. However, there are also freight forwarding companies which claim that the increase in shipments is not very significant or even decreases. Increasing the number of orders in e-commerce, supported by services provided by courier services is also growing, ranging from tracking systems, e-wallets, to multidrop. The tracking system allows consumers to monitor online courier services who are on duty delivering their goods. While e-wallet is a payment process that can be used by consumers, so there is no need to trouble transferring or paying directly in cash, while the multidrop system allows consumers to send goods from one origin to several destinations in one shipment. Vice versa, consumers can send goods from several goods to one destination.

\section{Conclusions}

Corona Virus Outbreak has increased new users in online shopping and certainly in the future has the potential to make the e-commerce industry through regulations made by orders namely Work From Home so that there is no activity outside the home as a sales channel that will increasingly grow well.

However, due to the condition of Indonesia's territory which has as many as 17,000 islands, the logistical aspects of both shipping costs and lead time of delivery become one of the main keys in the long run, so that the concept of centralized e-commerce logistics as it is now will remain an obstacle to growth during the Covid-19 subsided and market conditions returned to normal. Thus, the decentralization of e-commerce logistics is the key and the omni channel solution is the solution for Indonesia's e-commerce integration going forward.

In order for this outbreak to end soon, we ask that we both remind each other in order to maintain a healthy lifestyle, eat healthy food and also stay at home.

\section{Acknowledgment}

Researchers would like to express their deepest gratitude to all parties who have helped, especially to the Faculty of Economics and Business, University of Lampung who have helped with funding. 


\section{References}

[1] Kotler, Philip, \& Keller, K. L. Marketing management. Pearson Prentice Hall, 2009.

[2] Baum, David. "Business Links,” Oracle Magazine, no.3, Vol.XIII, pp.36-44, May/June 1999.

[3] Setiadi, Nugroho. Perilaku Konsumen Konsep dan Implikasi untuk Strategi dan Penelitian Pemasaran. Jakarta : Kencana Prenada Group, 2008.

[4] Kotler, P. and Armstrong. G. Principles Of Marketing. Englewood Cliffs, N.J.: Prentice Hall, 2010.

[5] Kotler, Philip, and Armstrong, G. Principles of Marketing. Upper Saddle River, New Jersey: Prentice Hall, 2012.

[6] Crosbie, T., \& Moore, J. Work-life balance and working from home. Social Policy and Society, 3(3), 223, 2004.

[7] Unknown. (2020, Mar.26). Pengertian Work From Home (WFH) dan Tipsnya. Available:

https://www.jurnal.id/id/blog/wfh-pengertian-dan-tipsnya/

[8] Pandjaitan, Dorothy. Aripin, Ahmad. Metode Penelitian untuk Bisnis. Penerbit Aura, 2015.

[9] Sugiyono. Memahami Penelitian Kualitatif. Bandung: CV. Alfabeta, 2005. 